日臨外医会誌 $53(11) ， 2638-2644 ， 1992$

原著

膵頭十二指腸切除術後の膵腸縫合不全に起因寸る腹部大量出血例の検討

東京女子医科大学消化器外科 (主任：羽生富士夫教授), 同 消化器放射線科* 小松永二今泉俊秀磯部義憲" 鈴木 木衛

中迫利明小形滋彦吉井克已原田信比古

木村健羽鳥隆羽生富土夫

脺頭十二指腸切除術後の膵腸縫合不全に起因寸る大量出血例の発生状況，出血状況， 治療法につき検討した。対象は1968年から1989年までに教室にて施行した膵頭十二指腸 切除術例565例である。1）膵腸縫合不全に起因する大量出血は16例であった。 2) 腹腔内 出血12例，消化管出血 4 例であった。 14例が明らかなショック状態に宿った。 3）止血法 の内訳は臣迫止血 4 例, 開腹手術 8 例, 経カテーテル的動脈塞栓術（TAE）4 例であっ た．4）開腹手術では出血部位を確認できたのは 3 例のみであったが，TAE 例では全例 確認可能であった，5）压迫止血，開腹手術例では全例死亡したが，TAE 例では1例を 失ったが， 3 例を救命できた。腈頭十二指腸切除術後の大量出血はいまた致命的な合併 症であり，ます繫急止血を第一に考光，TAEを第 1 巽択とすべきであると考えられた。

索引用語：荟頭十二指腸切除術，脺腸縫合不全，術後出血，経力テーテル的動脈塞栓術 (TAE), Interventional angiography

\section{緒言}

近年, 膵頭十二指腸切除術 (以下 PD)に打いては術 前術後管理，手術手技等の進歩に伴いその安全性も向 上し，適応む拡大されてきている。しかしながら膵腸 吻合䋖合不全はいまた重篤な合併症であり，その頻度 は近年減少しつつあるるのの，いまたなお数\%の頻度

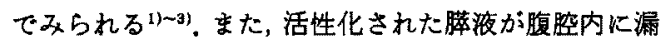
出すれば，特に血管周囲の郭清をしている場合，血管 は容易に破䅠を起こし，大量出血を引き起こす。

今回教室にて経験した PD 後膵腸縫合不全に起因す る大量出血例を対象に，出血状況招よび各種止血法の 有効性を比較検討した。

対象と方法

1968年から1989年12月までに教室にて経験したPD 565例を対象に（肝膵同時切除例を除く），膵腸䋖合不 全の発生率の推移，脺腸縫合不全例の転㷌を検討した。 尚，膵腸桻合不全は消化管造影，瘦孔造影，おょびト レーンからの腸内容, 胆斗を伴5膵液の排出の有無に

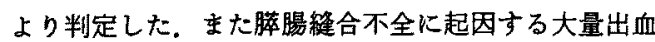
16例を対象に，その頻度，出血状況を検討し，さらに

1991年 1 月 7 日受付 1992年 8 月24日採用
王迫保存的止血群 ( 4 例), 開腹手術群 ( 8 例), 経力 テーテル的動脈塞栓術 (以下 TAE) 群 (4例) に分け 止血法, 止血効果, 転帰につき検討した。尚, 大量の 出血とは出血時に血王などの vital signに変化を及活 した数百 $\mathrm{ml}$ 以上の出血とした.

\section{成 繶}

1）膵腸䋦合不全発生頻度とその転㸟

1968年より1989年12月までに教室にて施行した肝膵 同時切除を除く PD は565例である.万ち膆腸縫合不全 は計61例に認めた(表 1)，その発生率の推移は，前期 （1968 1979）16.5\%, 後期（1980 1989）8.9\%と伍 は半减していた(表 2)，脺腸繾合不全例の転慢は，前 期では膵腸縫合不全23例の5ち，軽块退院 9 例，敗血 症, DIC, 多䁍器不全 (以下 MOF) 等にて死亡は14例 で，5ち大量出血死亡 6 例であり，入院時死亡率は14/ 23例（61\%)であった，後期では縫合不全38例のらち 軽快退院28例, MOF 等にて死亡は10例で，らち大量出 血死亡 7 例で，入院時死亡率10/38例 (26\%) であった （表 2). 入院死亡率子著明に減少しているが，特に最 近 5 年間は，膵腸縫合不全18例の5ち入院死亡は 2 例 のみであり，2 例とも大量出血死亡例であった。尚， 臨床的には縫合不全が明らかでなかった出血例 3 例は 


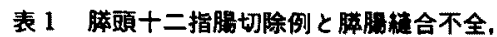
大量出血例

\begin{tabular}{|c|c|c|c|}
\hline & 应例 & 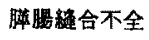 & 大量出血 \\
\hline \multicolumn{4}{|l|}{ 㥶生珗患 } \\
\hline 䐙頭部满 & 199 & 14 & 3 \\
\hline 乳㽬部痖 & 98 & 13 & 4 \\
\hline 䏣管照 & 74 & 19 & 4 \\
\hline 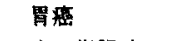 & 44 & 7 & 3 \\
\hline 十二指䐎重 & 13 & 2 & 0 \\
\hline 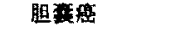 & 10 & 0 & 0 \\
\hline その他 & 5 & 0 & 0 \\
\hline \multicolumn{4}{|l|}{ 良生疾患 } \\
\hline 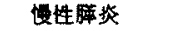 & 92 & 5 & 2 \\
\hline 朝胆繁合流異常 & 9 & 1 & 0 \\
\hline 睡青胞 & 6 & 0 & 0 \\
\hline モの他 & 15 & 0 & 0 \\
\hline 計 & 565 & 61 & 16 \\
\hline
\end{tabular}

\section{表 2 膵腸綎合不全と転粞の推移}

\begin{tabular}{|c|c|c|}
\hline & $1968-1979$ & $1980-1989$ \\
\hline 羘渴程合不全 & $\begin{array}{c}23 / 139 \\
(16.5 \%)\end{array}$ & $\begin{array}{l}38 / 426 \\
(8.9 \%)\end{array}$ \\
\hline 転惜 & & \\
\hline 退院 & 9 & 28 \\
\hline 死亡 (DIC, MOF 等) & 14 & 9 \\
\hline 大量出血 $(+)$ & 6 & 7 \\
\hline 大量出血 ( & 8 & 2 \\
\hline 他病死 & 0 & 1 \\
\hline
\end{tabular}

表 2 の検討では除いた。

\section{2）大需出血頻度}

脺腸腱合不全に起因する大量出血は胆管癌 4 例，乳 頭部癌 4 例, 胃癌 3 例, 膵頭部癌 3 例, 慢性勝炎 2 例 の計16例で，全体の $2.5 \%$ ，膵腸程合不全例の26\%で あった（表 1 )。

3）出血状況（表 3）

大量出血時期は，術後 6～51日(平均21日)，释合不 全確認後 3－31日（平均13日）であった。出血形式は 主に腹腔内出血12例，消化管出血 4 例であった，8例 に大量出血の数日前にドレーンからの血性浸出液や中 等量の出血などの前駆出血を数度みたか，自然止血， 王迫止血等にて止血されていた，出血時14例は明らか なショック状態に陌った。

4) 止血法の内訳と变逗（表 4)

初期においては開腹手術することなく4例に王迫的 止血等にて一時的止血を試みたが，出血を繰り返し死
表 3 出血状況

\begin{tabular}{|c|c|}
\hline \multicolumn{2}{|l|}{ 出血時期 } \\
\hline 郝 & 6-51日（平均21日） \\
\hline 䋃合不全磼諮後 & 3-31日（平均13日） \\
\hline \multicolumn{2}{|l|}{ 出血形式 } \\
\hline 腹运内出血 & 12例 \\
\hline 消化管出血 & 4例 \\
\hline \multicolumn{2}{|l|}{ 前駆比血 } \\
\hline 有 & 80 例 \\
\hline 無 & 8例 \\
\hline \multicolumn{2}{|l|}{ 全身状態 } \\
\hline$シ ョ ッ ク$ 有 & 14例 \\
\hline ショック 無 & 2例 \\
\hline
\end{tabular}

表 4 止血法の内㸽と空远

\begin{tabular}{l|c|c|c|c}
\hline & $\prime 68-' 79$ & $' 80-' 84$ & $' 85-' 89$ & 計 \\
\hline 保存的治療 & 4 & 0 & 0 & 4 \\
祅腹手街 & 4 & 3 & 1 & 8 \\
TAE & 0 & 0 & 4 & 4 \\
\hline
\end{tabular}

\section{表 5 出血部位確學}

\begin{tabular}{|c|c|c|c|c|}
\hline \multicolumn{3}{|c|}{ 開腹手術例 $(n=8)$} & \multicolumn{2}{|l|}{$\mathrm{TAE}$ 例 $(\mathrm{n}=4)$} \\
\hline 脾動脈 & 1 & & 胃十二指腸動脈断端 & 2 \\
\hline 脾静脈 & 1 & & 脾動脈 & 1 \\
\hline 傽断端噮死部 & 1 & & 背側膘動脈 & 1 \\
\hline 磼㦞不可 & 5 & & & \\
\hline \multicolumn{2}{|c|}{ 開腹時少贵出血の又 } & 3 & & \\
\hline \multicolumn{2}{|l|}{ 到達不可 } & 1 & & \\
\hline \multicolumn{2}{|c|}{ 大出血で確億不可 } & 1 & & \\
\hline
\end{tabular}

亡した. その後は開腹手衍を 8 例に, TAEを 4 例に施 行したが，最近 5 年間はTAEを主に行っている。

5）出血部位確認（表 5)

開腹手術例においては術中明らかな出血部位を確認 できたのは 3 例のみで，脾動脈 1 例，脾静脈 1 例，膵 腸吻合部の脺断端壊死部動脈 1 例であった。他の 5 例 は明らかな出血部位を確認できなかった，内，3例は 開腹時，腹腔内に血液，凝血塊を認あるす，すでに少 量出血のみであり臨床像に合致するような出血部位を 確認できなかった。 また 1 例は瘾着，肉芽形成が高度 であり，出血が疑われる深部束で致達できず，牫り1 例は開腹するる余りの大量出血にて出血部位を確認で きなかった。これに対し，TAE例では 4 例全例に仮性 動脈㢞または造影剂の血管外漏出として出血部位を確 認できた．胃十二指腸動脈断端 2 例，脾動脈 1 例，背 側膵動脈 1 例であった。 


\section{6）開腹手術例の検討（表 6 ）}

出血に対して開腹手術は 8 例に行われた, 術式は止 血ドレナージの他に膵管結惄 1 例, 膵管外瘦 2 例, 残 存膵脾切除が 2 例に行われた， 1 例は余りの大量出血 のため压迫止血のみ，1例は庱着, 肉芽形成高度で出 血部位まで致達できず開腹のみに終っている，術中出 血量は230 -6, $000 \mathrm{ml}$ (平均 $1,620 \mathrm{ml}$ ) で, 術中輪血も 400 6, $200 \mathrm{ml}$ (平均 $1,770 \mathrm{ml}$ )を要した。止血成續は 2 例は止血不可であり，手術により止血をみた 6 例中 2 例は早期に死亡， 4 例に再出血をみた，転帰は全例再 手術後 2 21日の間に死亡した。死因はほとんどが多 臓器不全, DICで, 再出血を契機に全身状態の悪化を み, 死亡した。

\section{7) TAE 例の検討（表 7 ）}

$\mathrm{TAE}$ は 4 例に行われた. 塞栓部位と塞栓物質は脾 動脈を steinless coil にて塞栓したもの 1 例, 左肝動脈 （胃十二指腸動脈分岐部）を steinless coil と cyanoacrylateを用いて塞栓したもの 1 例, gelatin sponge を 用いたもの 1 例，腹腔動脈を baloon catheter を用い た一時的に閉塞したもの 1 例であった，成績は全例止 血に成功し循環動態の急激な改善をみた。 3 例は止血 に成功救命し退院したが, baloon catheterによる止血 例は baloon 解放後再出血をみ肝不全, DICにて死亡 した，合併症としては，1 例に塞栓後のCTにて限局 性脾梗塞をみたが臨床的には問題とはならず，1例に cyanoacrylate 逆流によるとおもわれる脾膿瘍をみた が穿刺ドレナージにて治瘜した。

\section{表 6 開腹手術 8 例の術式と成績}

\begin{tabular}{|c|c|c|c|}
\hline 症例 & 術式 & 成䅨 & 転壋 (再手術後) \\
\hline 1 & 止血ドレナージ & 止血 & 死亡（2日） \\
\hline 2 & 止血ドレナージ,䐙外媦 & 止血 & 死亡（3日） \\
\hline 3 & 止血ドレナーシ，臊外㻲 & 止血 $\rightarrow$ 再出血 & 死亡（12日） \\
\hline 4 & 止血ドレナージ,䐙管結禁 & 止血 $\rightarrow$ 再出血 & 死亡 (10日) \\
\hline 5 & 残存愺脾切除 & 止血 $\rightarrow$ 再出血 & 死亡（10日） \\
\hline 6 & 残存羘脾切除 & 止血 $\rightarrow$ 再出血 & 死亡（21日） \\
\hline 7 & 王迫止血 & 止血不可 & 死亡（0日） \\
\hline 8 & 開腹のみ & 止血不可 & 死亡（4日） \\
\hline
\end{tabular}

\section{症例}

症例 $1 ： 65$ 歳男性. 膵頭部癌にて全胃幽門輪温存 $\mathrm{PD}$, 門脈合併切除を施行した. 術後 8 日目より膵腸縫 合不全を認め, 少量出血を繰り返した後19日目に突然 のドレーンからの大量出血をみ, 直ちに血管造影を施 行した。腹腔動脈造影にて膵断端近傍の脾動脈本幹に 造影剤の血管外漏出を認めた (図 1a). 本例は全胃温存 PDで左胃動脈が温存されていたため，左胃動脈から

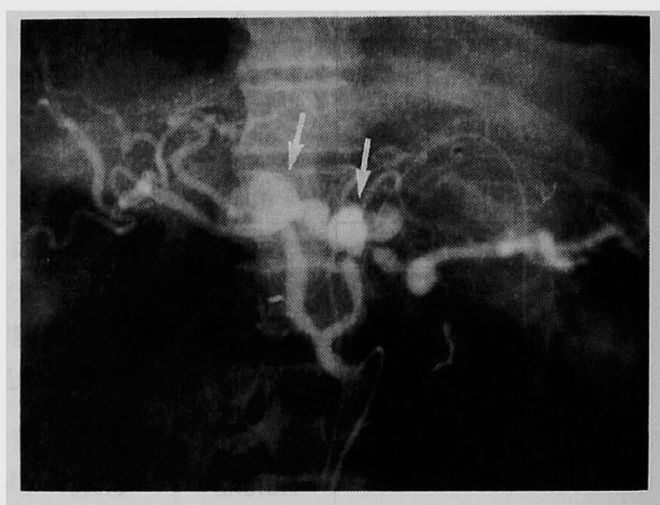

a)

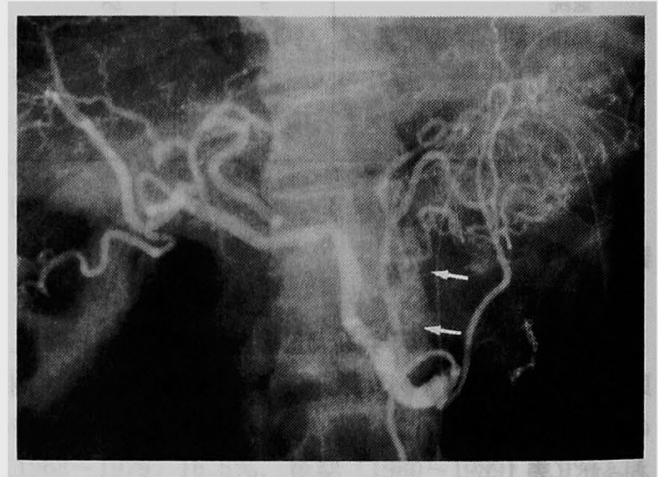

b)

図 1 腹腔動脈造影

a) 出血時：脾動脈よりの extravasationを認める (矢印)。b) 脾動脈 TAE後: 脾動脈は造影されず extravasationす認めない（矢印：金属コイル)

表 7 TAE 4 例の治療と成緛

\begin{tabular}{|c|c|c|c|c|c|c|}
\hline 应例 & 出 血 部 位 & 塞栓部位 & 塞栓物筫 & 成 績 & 合併症 & 転帰（止血後） \\
\hline 1 & 脾 動 脈 & 脾動脈 & 金属コイル & 止血 & 脾梗塞 & 退院 (80日後) \\
\hline 2 & 胃十二指腸動脈 (左肝動脈分岐) & 分岐部 & 金属コイル Cyanoacrylate & 止血 & 脾膿痗 $\rightarrow$ ドレナージ & 退院 (57日後) \\
\hline 3 & 胃十二指腸動脈 (左肝動脈分岐) & 分岐部 & Gelatin sponge & 止血 & な し & 退院 (24日後) \\
\hline 4 & 背側腪動脈 & 腹腔動脈 & ヘルーンカテーテル & 止血 $\rightarrow$ 再出血 & 肝不全 DIC & 死亡 (13日後) \\
\hline
\end{tabular}


短胃動脈を介しての脾，残存膵への血流を期待し脾動 脈を steinless coil にて塞栓した。，塞栓後の腹腔動脈造 影では脾動脈は根部より末梢は造影されず(図 lb), ま た左胃動脈から短胃動脈を介しての脾への血流も確認 された. 塞栓止血にて循環動態は急激に改善した。塞 栓後 7 日後の CT にて脾に部分的に低吸収域を認め脾 梗塞と診断したが，臨床症状もなく問題とならず，止 血後80日目に退院した。

症例 $2 ： 54$ 瓷, 男珄. 膵頭部癌にて PD, 門脈合併切 除を施行，術後 6 日目より膵腸縫合不全を認め，少量 の出血を絽り返した後，20日目ドレーンより突然の大 量出血をみ，直ちに血管造影を施行した，術前血管造 影では右肝動脈は胃十二指腸動脈分岐部より中权側で 分汥する解剖学的偏位が認められた(図 2a). 出血時腹 腔動脈造影では胃十二指腸動脈切離断端からの造影剂 の血管外漏出を認めた(図 2b). 右肝動脈は根部より造 影されず，術中操作による血栓形成等が疑われた。 のため左肝動脈を塞栓することにより肝への動脈血流 は失われるが, 門脈血流，下横隔膜動脈等よりの血流 を期待し，胃十二指腸動脈分岐部末梢より中权側にか けて肝動脈を steinless coil にて塞栓, さらに cyanoacrylate を追加した. 塞栓後の腹腔動脈造影では肝動脈 は造影されず，止血に成功した(図 2c). 止血後循環動 態は急激に改善した。止血翌日 GOT 230KU, GPT 150 KU と上昇を認めたが，4 日後にはほぼ正常値に回復 し, 䀒不全はみられなかった. しかしながら，止血後 8 日目より発熱を生じ，CT にて脾膿湯形成を認めた。 原因としてはsteinless coilにて塞栓後, 追加した cyanoacrylate が脾動脈に逆流した可能性が考皇られ た，穿刺ドレナージを施行し，軽快治箅し，止血57日 後退院した。

\section{考察}

PD 後には一般の術後合併症の他に, 胆腸縫合不全, 脺腸挥合不全等の特有の合併症がみられる。なかでも 膵腸艇合不全はその発生頻度は低下したものの，いま た腹腔内膿瘍や出血を引き起こす重篤な合併症であ $3^{1) 2)}$. 膵腸縫合不全例の転㷌は, 初期においては敗血 症, DIC, 多䁍器不全による死亡例が多くみられたが, 最近においてはこれらによる死亡例は著減し，特に最 近 5 年間をみると入院死亡例は出血例の 2 例のみであ る.周術期管理の進歩等により，敗血症，DIC 等によ る死亡は著減し，むはや克服されたとも考えられるか， いまだ出血は致死的な問題である ${ }^{3)}$.

教室では過去22年間に16例の膵腸縫合不全に起因す

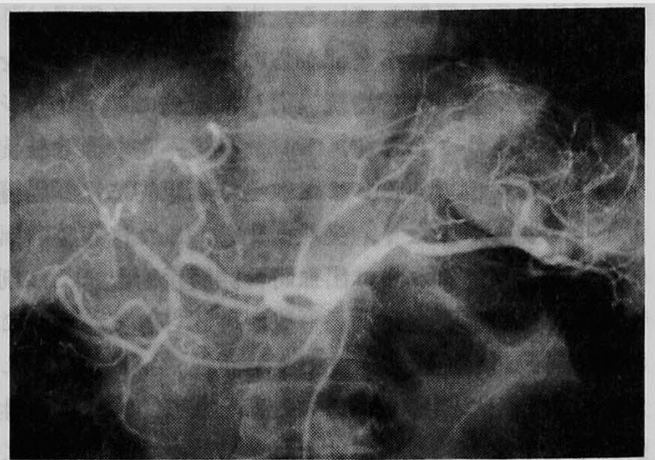

a)

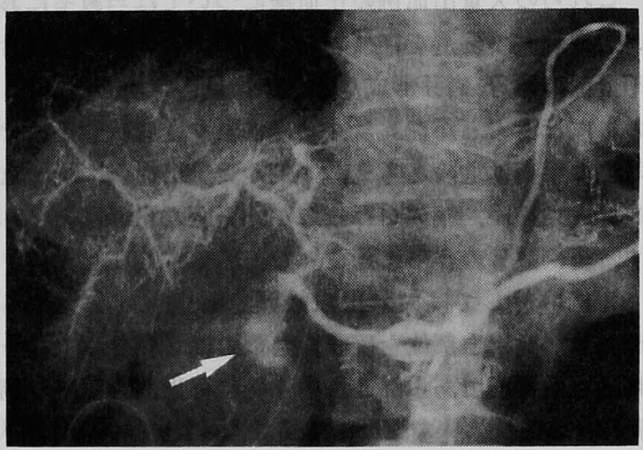

b)

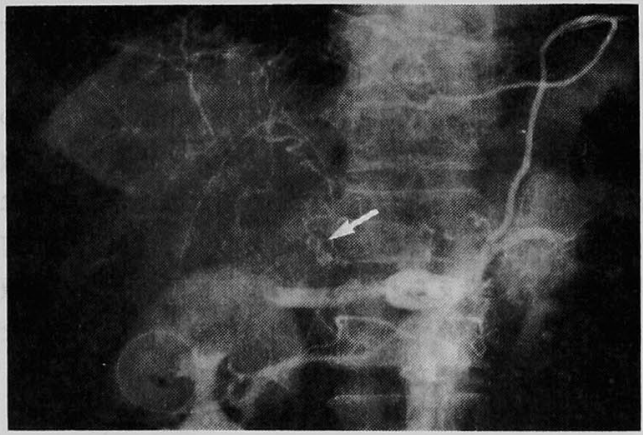

C)

図 2 腹腔動脈造影

a）術前：右肝動脈が胃十二指腸動脈分岐部より中枢 側より分岐している。

b）出血時：胃十二指腸動脈断端よりの extravasationを認める (矢印). 右肝動脈は根部より造影され ず，術中操作等による血栓形成が疑われた。

c）TAE後：固有肝動脈は造影されず, extravasation b認めない(矢印：金属コイル). 
る大量出血例を経験している，出血にいたる経過は， ほとんどが膵腸艇合不全部からの膵液，腸内容漏出を 創部からのドレーンで持続吸引し積極的にドレナージ していたにるかかからず，ドレナージ不良で血管破綻 を起こした症例である。また数例は䁒床的には膵腸縫 合不全が明らかでなく，突然消化管，または腹䶼内出 血をきたした，これらは出血時の開腹手術，または剖

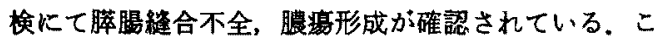
の様に脺腸艂合不全に対するドレナージ不良例は，し だいに腹腔内に膿㷎を形成する事となり，血管に仮性 動脈㿇を形成し，ついにはそれが破綻し大出血を起こ すと考えられる。

これらの大量出血例の止血法については当教室に和 いても数度の变遷を経てきた、初期に括いては，縫合 不全部の族着, 肉芽形成が強く手術は困難が予想され， さらに注とんどがショック状態にあり全身状態不良で 即坐の手術は危険と考え，4例の大量出血例に王迫止 血，大量輸液，输血を行ったが，完全な止血はえられ ず，全例数日のうちに死亡した。

8 例に対しては大量出血後緊急開腹手術を施行し た、しかし出血部位を確認できたのは3例のみで，一 時的止血可能であった 6 例中 4 例に再出血をみ，全例 死亡するという，渗涺たる結果であった。横溥ら゙す膵 腸释合不全 8 例の5ち3 例に出血をみ，5ち2例に再 開腹，止血，膵管外瘦術を行ったが，24日目，37日目 に死亡したと報告している.三富ら゙ PD後, 絴合不 全のある出血例に対し，開腹止血術を施行しているが， 1 例は 2 日後に死亡, 1 例は 3 回の再出血をみ 2 回の 再々手術の後，3回目に経カテーテル的此血術にて救 命している，满腸縫合不全による出血の場合，血管は 脆弱化して括り血管の部分的結禁のみでは再出血の可 能性は充分に考えられる。このように開腹手術の治療 成績は極めて不良であるが，その他の有奻な方法がな く手術せざるをえなかったのが実情であった。

出血に対するTAEは1972年に Rösch ら”により， 十二指腸漬湯出血に対して自己凝血塊を用い止血した ことに始まった，それ以来種々の病態に招ける出血に 適応されるようになってきた7タ).当教室に批いては早 期より術後す含めた急性大量出血例に TAEを適応と してきたが, PD 後の膵腸䊕合不全に起因する場合, 原 因である繾合不全を解決しない限り再出血をさたすと

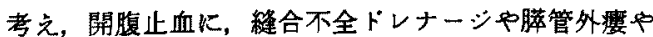
残存脺全摘を加えた手術を行い，絴合不全と出血を一 気に解決する治療法を選択してきた。しかしこれらの
開腹手術例の治療成緩は極めて不良であり，この上5 な状態において乎術といら侵俥を加えるよりる，まず 第一にTAEにて止血し，全身状態の改善を待って2 期的に䋖合不全に対する処置を行らべをと考学た。 そ こで1986年以降 4 例の出血例に TAEを行った，出血 に対するTAEの利点としては，出血後直ちに施行で きる，全身麻酔が必要ない，侵貿が軽度である，出血 部位を確認しやすい，処置による出血がない，止血成 績も良好，藏器温存ができる等があげられる、TAEを 施行した 4 例とす出血後数十分のらちに血管造影を開 始でき，全例出血部位を確認できた，全例止血に成功 し，止血後血正等の循䍘動態の急激な回復がみられ， 緊急止血効果としては満足な結果がえられた。 baloon catheter による止血例に再出血を死亡したが，他の 3 例は永久止血できた。このよ5にTAE導入により 脺腸縫合不全による出血例の止血率，救命率は劇的に 改善された。脺腸縫合不全も TAEによる止血後，2期 的に X 線透視下などによるドレーン操作によりドレ ナーシす良好となり治海し退院できた。 むちろん症例 によってはTAEによる止血後膵腸縫合不全に対して は開腹手術を含めた積極的な処置が必要である，要は 出血と繾合不全の观置は別々に考え，ますは救命的止 血を第 1 に考え, TAEにて止血し，後に全身状熊の改 善を待って，膵腸縫合不全に対する処置を行らべきで ある。TAEにて止血困難な場合には開腹術すやむを 得ないが，血管造影は治療法決定に出血部位等重要な 情報を提供する。

TAEに一般に用いられる塞栓物質は, gelatin sponge, steinless coil, cyanoacrylate 等である, 消 化管出血の場合は消化管壁内枝の上5に末梢の細かい 血管からの出血のことが多く、vasopressin 動注療法 や, gelatine spongeによるTAEにて良好な止血成績 が兄られている9110\}.しかしながら PD後の出血の場合 は，罢十二指晹動脈断端や脾動脈などの比較的太い血 管の破綻による出血が多く, vasopressin p gelatine sponge による止血は困難であり, steinless coil キballoon catheter による止血が適している11'.中权性に限 局した内腔の塞栓であるため，その末梢への側副血行 が期待でき，末梢臟器への障害を軽唡にとでめること あできる，1つの coil では止血効果は弱く必ず 2 個以 上の coil を使用すべきとされている．また確実な止血 法と乙ては出血部位をはさむような形で末梢側，中枢 側を同時に coilにて塞栓するのが理想的であるが，出 血部位血管や動脈瘤は脆弱であり，これを越えて末梢 
までカテーテルを㨀入することは困難なこともあり， 中权側の TAE しかできないこともある，1例は cath eter 先端が不安定で誤择入の危険があるため gelatine spongeを用いた。

腹腔動脈周用からの出血例には，PDに拈いては胃 十二指得動脈，左胃動脈，下膵十二指腸動脈，背側膵 動眽等の血管が切離されており、これらからの側副血 行は期待できず，腹空動脈本幹の一期的永久止血は，

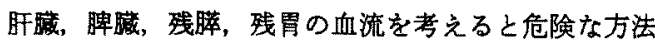
と考えられる，そこで腹腔動脈近傍よりの出血例に腹 腔動脈を baloon catheterにて閉塞し一時的に止血に 成功した。この方法では baloon 解放後の再踈通む期 等でき，万一の再出血に対しても追加処置可能と考兄 た.しかし肝不全，解放後の再出血定生じ死亡した。 町田 ${ }^{(2)}$ は PD 後の腹腔動脈根部からの出血例に腹腔 動脈根部を coil, Gelfoam 細片にて TAE L, TAE 後 の腹腔動脈造影では末梢はまったく造影されず，上腸 間膜動脈造影では膵頭部の細動脈を介して腹腔動脈領 域が造影され，同領域の血流が保たれていることが確 認されたとしている. 中崎ら ${ }^{13)}$ は PD後の出血に対し Swan-Ganz catheterを用い，バルーン前後の血王を モニターし，ある程度の血流をを保ちながら，その間 に他の部位からの側副血行路による血流改善を促す方 法を考え止血に成功しており，腹腔動脈本幹の止血に はこのような工夫が必要と考えられた。

肝動脈の塞栓は，左右の1本であれば，肝障害は問 題とならない，固有肝動脈の塞栓例も報告されてお $\eta^{14)}$, 肝不全等の重第な合併庭は見られず，われわれの 症例です1例は肝動脈の血流を失ったが，直後にトラ ソスアミナーゼの軽度上留を認めたが 4 日後には回復 し、肝不全等は生じなかった。肝臓は門脈血流ととす に横隔膜下動脈等からの側副血行が期待でき，固有肝 動脈の TAE 可能と考えられるが，肝不全を念頭に おいた钼重な管理が必要である。

脾動脈の塞栓は，われわれの症例では全胃幽門輪温 存例であり，左胃動脈が温存されており，左胃動脈か らの脾への血流を期待し脾動脈を塞栓した，塞栓後の 造影です左胃動脈からの脾への血流が確認できた，止 血後のCTにてわずかな脾梗塞を認めたが，臨床的に は問題とならなかった。しかし悪性疾患に対するPD Кおいては，左胃動脈，背側脺動脈を切離することが 多く, 脾動脈以外からの副血行路の期待は少ない。 の上うな状態に招ける脾動脈からの出血には救命のた めに脾動脈を塞拴せざるをえないか，TAE後の残存
膵，脾の梗塞，壇死には十分注意を要し，䈯重な管理 が必要である。

$\mathrm{PD}$ 後には腹腔内の種々の血管が切離されており， その血行動態は側副血行のできにくい状態にある，ま た症例により切離された血管や血行状態る巽なる。こ の様な状態に肝，脾動脈等の主要血管を塞栓するこ上 はある程度の危険を伴うと考えられる。しかしながら 開腹手術等の他の止血操作で良好な成續が得られてい ない現状では，膵腸綎合不全に起因する大量出血例に は血管造影、TAEを第一選抧とすべきであり，たと党 TAEが困難な例であっても血管造影により出血部位 等の重要な情報が得られる。

\section{結語}

1） $\mathrm{PD}$ 後の膵腸絴合不全に起因する大量出血につ き険討した。

2） PD 565例中膵腸縫合不全は61例にみられ内16例 に大量出血を認めた。

3）出血に対する止血では，王迫止血のみ，開腹手術 では，出血部位確認，止衈成績す不良で全例が死亡し た.

4) TAEで恃出血部位確認，止血成績る良好で 4 例 中 3 例を救命でさた。

本論文の要旨は第36回日本消化器外科学会總会にて発表 ᄂた.

\section{女献}

1) 羽生富士夫，今泉俊秀：膵渴吻合術，外科治療 $49: 129-141,1983$

2）新井田達雄，羽生富士夫，今泉段秀他：膵頭十二指 晹切除術500例の早期合併庭の検討, 膵䁍 $3: 27$ $-34,1988$

3）小松永二, 今泉俊秀, 鉿木 㽞他：膵の性状に応し た膆腸吻合の工夫と膵腸释合不全の対策。第14回 日本膵奶矿究会ブロシーディンダス, 56-57, 1990

4) 横港清司, 中山和道, 江里口直文他：膵手術に挌け る術後合併应とその対策，外科治療 $62 ： 533$ $-537,1990$

5）三富利夫, 杉田輝地：消化器手術後の腹腔内出血 とその対策, 外科䛦潦 $22: 1601-1605,1981$

6) Rösch J, Dotter CT, Brown ML: Selective arterial embolization. Radiology $102: 303-306$, 1972

7) Athanasoulis $\mathrm{CA}$, Waltman $\mathrm{AC}$, Ring EJ, et al : Angiographic management of postoperativ bleeding. Diagnostic Radiology 113: 37-42, 1974 
8）井户邦雄，柄本 梳，平松京一：出血に対する TAE 法, 攵急医 $12: 1735-1744,1988$

9) Rahn NH, Tishler JM, Han SY, et al: Diag. nostic and interventional angiography in acute gastrointestinal hemorrhage. Diagnostic Radiology $143: 361-366,1982$

10) Lieberman DA, Keller FS, Katon RM, et al : Arterial enbolization for massiv upper gastrointestinal tract bleeding in poor surgical candidates. Gastroenterology $86: 876-885,1985$

11）森田租，斉藤博哉，篠原政裕他：術後腹腔内出血
に対する経動脈カテーテル塞栓術, 北海道外科誌 $32: 165-172,1987$

12）町田浩道, 小息幸次郎, 中谷雄三他：膵頭十二指渴 切除術後の腹整内出血比対する動脈塞栓術，日外 会誌 $91: 705-712,1990$

13）中崎久雄, 三富利夫，田島知郎他：膵頭十二指腸切 除術後に発生した難治性出血に対する新しい止血 の試み，外科 $42: 26-29,1980$

14）金井道夫，近藤成彦，㴫野正人他：腹部大量出血に 奶する緊急経カテーテル的動脈塞栓術の有用性に つて, 日消外会誌 $21: 1301-1307,1988$

\title{
A CLINICAL STUDY OF MASSIVE ABDOMINAL BLEEDING DUE TO LEAKAGE OF PANCREATOJEJUNOSTOMY IN POSTPANCRETODUODENECTOMY
}

\author{
Eiji KOMATSU, Toshihide IMAIZUMI, Yoshinori ISOBE, Mamoru SUZUKI, Toshiaki NAKASAKO, \\ Toshihiko OGATA, Katsumi YOSHI, Nobuhiko HARADA, \\ Ken KIMURA, Takashi HATORI and Fujio HANYU \\ Department of Surgery and Radiology, Institute of Gastroenterology, Tokyo Women's Medical College
}

The massive abdominal bleeding due to the leakage from the pancreatojejunostomy is one of the most lethal complication after pancreatoduodenectomy (PD). Subjects were 565 patients undergoing $P D$ at the department in a period from 1968 to 1989 . Of the 565 cases 16 developed massive bleeding due to anastomotic leakage. There were 12 cases bled from intraabdominal and 4 from gastrointestinal sites. Fourteen cases developed in shock. Hemostasis was made by conservative procedure in 4 , by laparotomy in 8 , and by transcatheter arterial embolization (TAE) in 4 cases. Of 8 cases undergoing laparotomy, exact bleeding site could be confirmed in only 3 cases, but in all cases undergoing TAE, the bleeding site was able to be confirmed. All cases undergoing surgery and conservative hemostatic treatment were lost, however, in 3 out of 4 cases undergoing TAE, their lives could be saved. In the treatment of such massive abdominal bleeding, we should consider the emergency hemostatis first and foremost and to select TAE. 